\title{
Approaching the child with headache
}

\author{
Abordarea copilului cu cefalee \\ Mioara Cristina AVASILICHIOAEI ${ }^{1,2}$, Mihaela Adela IANCU ${ }^{1,3}$, Dumitru MATEI ${ }^{1,4}$ \\ ${ }^{1}$ Universitatea de Medicină și Farmacie „Carol Davila“, București, România \\ ${ }^{2}$ Clinica Neurologie, Spitalul Clinic Colentina, București, România \\ ${ }^{3}$ Cabinet medical individual, București, România \\ ${ }^{4}$ Institutul Național pentru Sănătatea Mamei și Copilului „Alessandrescu-Rusescu“, \\ București, România
}

\section{ABSTRACT}

Headache is one of the most frequent symptoms for which patients seek medical attention from their family physicians. Typologies are different in children, compared to adults. Ethiologies and clinical features are diverse, accompanied, on occasion, by EEG changes. Against this background, it is the purpose of this article to give a rundown of the most recent research in primary and secondary headache with focus on a recently recognised clinical entity where headache and epilepsy intersect, namely epileptic cephalalgia. The result is meant both as a diagnostic and therapeutic tool for the use of family physicians and as an 'uptodate' on the latest headache research its applications.
\end{abstract}

Keywords: headache, children, clinical features, epileptic cephalalgia

\section{- REZUMAT}

Cefaleea este unul dintre cele mai frecvente simptome pentru care pacienții se prezintă la medicul de familie. Se descriu tipologii diferite de prezentare la copil față de adult, având etiologii și manifestări clinice diverse însoțite, în anumite cazuri, chiar de modificări la nivelul electroencefalogramei. În acest context, ne-am propus să oferim o scurtă trecere în revistă a celor mai recente aspecte privind cefaleea primară și secundară, cu accent pe o entitate nosologică recent recunoscută, aflată la granița cefalee-epilepsie, și anume cefaleea epileptică. Efortul constituie atât un instrument util în orientarea practică a diagnosticului și terapiei cefaleei de către medicul de familie, cât și un demers de actualizare cu privire la evoluțiile recente în cercetarea și aplicațiile privind cefaleea.

Cuvinte cheie: cefalee, copii, tablou clinic, cefalee epileptică

\section{INTRODUCERE}

Cefaleea - durerea localizată la nivelul extremității cefalice - reprezintă unul dintre motivele frecvente de prezentare a copiilor la medicul de familie [1]. De cele mai multe ori, părinții se îngrijorează și caută ajutor medical atunci când cefaleea interferă cu activitatea copilului, acesta nu se mai joacă sau absentează de la școală. Cefaleea poate fi determinată de cauze locale sau generale, intra- sau extracraniene, și poate repre- 
zenta un simptom al unei boli în evoluție [2]. Orientarea rapidă diagnostică a medicului de familie în fața unui copil cu cefalee se bazează pe anamneză minuțioasă și examen clinic general pentru evidențierea simptomelor și semnelor ce însoțesc cefaleea, în vederea realizării unui plan de investigații paraclinice [3]. Relativ recent, Societatea Internațională pentru Studiul Cefaleei (International Headache Society - IHS) a clasificat o noua entitate nosologică situată la granița cefalee-epilepsie cu relevanță pentru inițierea de către medicul de familie a unui diagnostic diferențial cât mai complet și adaptat ultimelor evoluții în domeniu.

\section{CLASIFICARE}

Intensitatea, sediul, caracteristicile durerii, durata și prezența simptomelor asociate - neurologice sau sistemice, sunt elemente importante pentru diagnosticul etiologic al cefaleei. Un copil poate prezenta, la momente diferite, mai multe episoade dureroase de etiologie diferită, ceea ce impune ca fiecare episod dureros să fie diagnosticat conform criteriilor stabilite de către International Headache Society (IHS), cu ultima actualizare din 2018 [4].

Cefaleea poate fi clasificată ca primară - cele intrinseci sistemului nervos (vezi tabelul 1) - și secundară (atunci când este asociată cu o stare patologică). Cefaleea secundară apare în relație temporală cu afecțiunea primară și/sau se rezolvă cu succes prin tratamentul stării patologice asociate (traumatism, infecții acute sistemice, anemie etc.) [2]. De remarcat faptul că cefaleea primară și cea secundară nu se exclud reciproc; pacienții cu o tulburare primară de cefalee pot prezenta o cefalee primară exacerbată de o etiologie secundară la un moment dat.

\section{CEFALEEA PRIMARĂ}

Cefaleea este un simptom comun în rândul copiilor și adolescenților (cu o prevalență de 37-51\% la copiii de 7 ani și creștere progresivă la 57-82\% până la vârsta de 15 ani), cefaleea primară migrenoasă aflându-se în topul celor cinci cele mai comune boli ale copilăriei [5]. Estimările arată că prevalența migrenei la nivel mondial este de 7,7\% (fără diferențe de gen între 4 și 11 ani, dar cu viraj către genul feminin după pubertate) și că aproximativ jumătate din populația pediatrică afectată de migrenă va continua să experimenteze crize și la vârsta de adult $[6,7]$. Printre factorii de risc cunoscuți se numără sedentarismul și obezitatea, consumul de alcool, tutun sau cafea în rândul adolescenților, lipsa de timp liber, așteptările mari ale părinților sau lipsa satisfacției personale, divorțul părinților și altele [6]. Migrena este tratată, în context acut, cu ibuprofen sau naproxen ca primă linie de acțiune, cu adăugarea unui triptan în caz de ineficiență a primei linii [5]. De asemenea, s-a raportat și eficiența combinației dintre acetaminofen și un compus pe bază de cafeină administrat la debutul crizei [8]. Tratamentul poate include și medicație antidopaminergică (proclorperazină și metoclopramid), antiinflamatorie (ketorolac), antiepileptică (valproat de sodiu), dihidroergotamină sau triptani în caz de status migrenos cu durată mai mare de 72 de ore. Pe de altă parte, terapia profilactică în cazul pacienților cu crize migrenoase foarte frecvente include antidepresivele triciclice, medicație antiepileptică (topiramat, acid valproic, levetiracetam, gabapentin sau zonisamidă), antihistaminice (ciproheptadină) sau antihipertensive (propranolol, verapamil) [5]. În curs de cercetare și aplicare la adulți, dar curând și în rândul populației pediatrice, sunt anticorpii mono-

TABEL 1. Clasificarea cefaleei - IHS 2018

\begin{tabular}{|l|l|}
\hline Cefalee primară & Migrena (cu aură, fără aură, cronică, cu status migrenos) \\
\cline { 2 - 3 } & Cefaleea de tip tensional (cu crize rare, frecvente, cronică) \\
\cline { 2 - 3 } & $\begin{array}{l}\text { Cefalalgii trigeminal vegetative (cluster episodică, cluster cronică, cefaleea nevralgiformă unilaterală cu/sau } \\
\text { fară hiperemie conjunctivală și lacrimație etc.) }\end{array}$ \\
\cline { 2 - 3 } & Alte cefalee primare (în lovitură de pumnal, asociată tusei, efortului fizic, activității sexuale, hipnică) \\
\hline \multirow{5}{*}{ Cefalee secundară } & Cefaleea atribuită traumatismelor cervicale și/sau craniene \\
\cline { 2 - 3 } & Cefaleea atribuită patologiei vasculare cerebrale sau cervicale \\
\cline { 2 - 3 } & Cefaleea atribuită afecțiunilor intracraniene nevasculare \\
\cline { 2 - 3 } & Cefaleea atribuită utilizării unei substanțe sau sevrajul acesteia sau cefaleea de abuz medicamentos \\
\cline { 2 - 3 } & $\begin{array}{l}\text { Cefaleea atribuită infecțiilor intracraniene (meningită, encefalită, abces cerebral, empiem) sau infecții } \\
\text { sistemice (respiratorii, digestive, renale) }\end{array}$ \\
\cline { 2 - 3 } & $\begin{array}{l}\text { Cefaleea atribuită tulburărilor homeostaziei (hipoxie, hipercapnie, hipertensiune arterială, hipotiroidism, } \\
\text { subalimentație etc.) }\end{array}$ \\
\cline { 2 - 3 } & $\begin{array}{l}\text { Cefaleea sau durerea facială atribuită patologiei craniului (afecțiunea oaselor craniului, oculare, afecțiuni ale } \\
\text { urechilor, sinusurilor paranazale etc.) }\end{array}$ \\
\cline { 2 - 3 } & Cefaleea atribuită afecțiunilor psihice \\
\cline { 2 - 3 } & Nevralgii craniene și cauze centrale de durere facială \\
\hline & Alte cefalee neclasificate în alt loc \\
\hline
\end{tabular}


clonali împotriva peptidului înrudit cu gena calcitoninei (CGRP) sau a receptorului acesteia [7]. Se poate remarca deja la acest moment că medicația antiepileptică este un numitor comun în tratamentul epilepsiei și al migrenei deopotrivă. Interesant de punctat este și faptul că atât cefaleea migrenoasă, cât și epilepsia se pot afla la baza apariției unui sindrom mai frecvent la copii, și anume sindromul Alice în Țara Minunilor, în care pacienții experimentează alterarea imaginii corporale cu augmentarea, diminuarea sau distorsiunea unor segmente corporale sau chiar a întregului corp, alterare pe care pacienții o percep ca fiind, totodată, ireală. Administrarea topiramatului pentru prevenția crizelor migrenoase la o pacientă de 17 ani a fost și ea citată într-un caz de sindrom Alice în Țara Minunilor, cu reversibilitate la sistarea medicației [9]. După migrenă, al doilea cel mai frecvent tip de cefalee primară la copii este cefaleea de tensiune, care, împreună cu migrena și cefaleea secundară benignă aferentă unor afecțiuni autolimitate, reprezintă majoritatea cazurilor de prezentare la medic, cele primare însumând procente între $21 \%$ și $66 \%$, iar cele secundare benigne între 35\% și 63\% [10].

\section{CEFALEEA SECUNDARĂ}

Prioritatea în evaluarea cefaleei la copii o reprezintă excluderea cefaleei care este secundară unor afecțiuni grave precum trauma, tumorile, infecțiile, inflamațiile, presiunea intracraniană crescută sau bolile metabolice și care are o frecvență mai mică, între 2 și 15\% [10]. La efectuarea acestei evaluări poate fi de ajutor acronimul mnemotehnic SNOOP4Y (vezi tabelul 2), care îndreaptă mai degrabă către o cauză secundară gravă [6].

TABEL 2. Semne de gravitate în evaluarea cefaleei la copii

\begin{tabular}{|l|l|}
\hline $\begin{array}{c}\text { Parametru în limba } \\
\text { engleză }\end{array}$ & \multicolumn{1}{c|}{$\begin{array}{c}\text { Parametru în limba } \\
\text { română }\end{array}$} \\
\hline Systemic symptoms & simptome sistemice \\
\hline Neurologic signs & semne neurologice \\
\hline Onset - sudden & debut brusc/brutal \\
\hline Occipital & localizare occipitală \\
\hline Precipitated by Valsalva & precipitată de manevra Valsalva \\
\hline Positional & modificabilă cu poziţia \\
\hline Progressive & progresivă \\
\hline Parents & absenţa antecedentelor familiale \\
\hline Years & vârsta mai mică de şase ani \\
\hline
\end{tabular}

Este mai puțin probabil ca cefaleea secundară să aibă un caracter recurent, cu câteva excepții. Printre acestea trebuie menționată cefaleea datorată hipertensiunii intracraniene idiopatice sau secundare (endocrinopatii, anemie, lupus, obezitate sau intoxicație cu vitamina A folosită de adolescenți în tratamentul acneei), ce este adesea asemănătoare unei migrene.
De asemenea, alte afecțiuni ce pot include cefaleea recurentă de tip migrenos în tabloul clinic sunt sindroamele metabolice precum sindromul MELAS (encefalopatia metabolică cu acidoză lactică și episoade similare accidentului vascular) sau sindromul CADASIL (arteriopatie cerebrală autozomal dominantă cu infarct subcortical și leucoencefalopatie). Cefaleea recurentă poate fi prezentarea inițială la $28 \%$ dintre pacienții cu sindrom MELAS, majoritatea cazurilor debutând între 2 și 20 de ani. În cazul sindromului CADASIL, ce afectează în special adulții tineri, dar care se poate întâlni și la adolescenți, migrena poate fi unica manifestare a bolii [5].

\section{CEFALEEA EPILEPTICĂ}

Din ce în ce mai multe date ale cercetărilor recente arată faptul că cefaleea poate fi unica manifestare și în cazul unui eveniment epileptic, diagnosticul fiind adesea greu de tranșat și adesea ratat cu eticheta de cefalee migrenoasă, posibil și pe fondul datelor de prevalență ce indică rate mai mari pentru migrenă comparativ cu epilepsia - 12\% și, respectiv, aproximativ $2 \%$ din populație [11]. Cefaleea critică - manifestă în timpul unei crize epileptice, fie în izolare, de sine stătătoare, fie ca parte a unei epilepsii cu mai multe manifestări - reprezintă doar 3-5\% dintre cazuri, restul cazurilor de cefalee ce apar în conjuncție cu epilepsia fiind fenomene majoritar postcritice $10-50 \%$ dinrte cazuri) sau precritic prodromice și intercritice $(5-15 \%$ dintre cazuri) $[9,12]$.

Fiziopatologia fenomenului cefalalgic epileptic critic nu este pe deplin elucidată, însă se pare că atât cefaleea migrenoasă, cât și epilepsia au o bază fiziopatologică comună prin excesul de excitare neuronală, descărcările focale din timpul unui eveniment critic și propagarea ulterioară a impulsurilor ducând la activare trigeminovasculară [11]. Mai concret, în cazul epilepsiei, hiperexcitabilitatea este urmată de hipersincronie și, ulterior, de supresie neuronală, iar în cazul migrenei hiperexcitabilitatea duce la un val depolarizant ce difuzează cortical cu creșterea fluxului de sânge, urmat de supresie neuronală, cu scăderea fluxului sangvin, acest efect de difuzie-supresie comun cu epilepsia ducând ulterior la activarea sistemului nociceptiv trigeminal, cu eliberarea de molecule neuroinflamatorii ce declanșează durerea. Cortexul occipital pare a fi mai vulnerabil la acest efect de difuzie-supresie [13]. Pragul pentru declanșarea efectului de difuzie-supresie din migrenă pare a se situa mai jos comparativ cu pragul necesar declanșării unei crize epileptice, ceea ce ar explica de ce instalarea unei crize epileptice ar favoriza apariția migrenei comparativ $\mathrm{cu}$ situația inversă în care apariția migrenei ar cauza o criză epileptică [14]. Alte studii indică disfuncții genetice 
ale unor canale ionice ca stând la baza mecanismului comun al producerii migrenei și epilepsiei [15] sau arată că descărcările implică sau chiar își au originea în ariile cerebrale de procesare a durerii (cortexul somatosenzitiv primar și secundar, insula, cortexul cingulat anterior, cortexul prefrontal, talamusul și amigdala), fiind demonstrat faptul că relevante pentru percepția durerii sunt în special cortexul somatosenzitiv secundar și insula. Această rețea multizonală explică, poate, de ce au fost depistate diferite focare în diferite cazuri de cefalee epileptică [16].

O analiză sistematică a bazei de date Pubmed realizată în anul 2017 a evidențiat mai bine de 30 de studii de caz ale unor pacienți cu cefalee ca unică manifestare epileptică, primul fiind descris în anul 1971, alte zece până în 2006, iar restul după această dată, sugerând posibilitatea subdiagnosticării în trecut [16].

\section{Cefaleea epileptică}

- Apariție la orice vârstă, inclusiv în rândul copiilor și adolescenților, afectând ambele sexe în mod egal

- Durată de la secunde la zile, duratele scurte fiind asociate mai frecvent cu focare temporale și anterioare

- Caracter migrenos sau de cefalee de tensiune sau nedefinit

- Simptome de acompaniere minore (fonofobie, fotofobie, greață și vărsături, paloare, dificultăți de vorbire, agitație, iritabilitate)

- EEG-ul din timpul crizei arată anomalii compatibile cu o criză epileptică ce debutează și se termină odată cu cefaleea (uneori depistabile doar cu electrozi de profunzime); modificări EEG intercritice posibile

- Răspunde în câteva minute de la administrarea unui medicament antiepileptic

FIGURA 1. Trăsături ale cefaleei critice epileptice (16)

Cefaleea epileptică a fost oficial recunoscută ca entitate nosologică (IHS; 2018) cu următoarea descriere: „Cefalee cauzată de o criză epileptică focală sau care apare în timpul unei asemenea crize, ipsilateral cu sediul descărcărilor epileptice și care se remite imediat sau la scurt timp după terminarea crizei“. Există patru criterii de diagnostic:

- orice cefalee ce îndeplinește criteriul al treilea de mai jos

- pacientul are o criză epileptică focală

- există dovada cauzalității demonstrată prin următoarele două condiții: 1) cefaleea a apărut simultan cu debutul crizei focale și 2 ) fie una sau ambele din următoarele - a) cefaleea este ipsilaterală descărcării critice sau b) cefaleea diminuă în intensitate sau se remite imediat ce criza epileptică a luat sfârșit

- cefaleea nu poate fi explicată de un alt diagnostic recunoscut în cea mai recentă (a treia) ediție a clasificării internaționale a sindroamelor cefalalgice
Este recunoscut, totodată, faptul că cefaleea critică epileptică poate să apară nu numai în formă pură, izolată, ca unică manifestare epileptică, necesitând diagnostic diferențial cu alte tipuri de cefalee, dar și că aceasta poate fi urmată de alte manifestări epileptice motorii, senzoriale sau autonome (IHS, 2018).

Studiile cu privire la biochimia și markerii biologici ai cefaleei epileptice sunt rare având în vedere noutatea relativă a subiectului, iar datele cu privire la populația pediatrică în mod special lipsesc. Exist însă câteva studii cu accent pe cefaleea migrenoasă care - dați fiind numitorii comuni fiziopatologici pe care îi împărtășește cu mecanismele epilepsiei amintiți mai sus - ar putea trimite cu gândul la potențiale similitudini. 0 metaanaliză publicată în 2017, spre exemplu, a constatat creșterea în lichidul cefalorahidian a pacienților cu migrenă a nivelului de glutamat (asociat hiperexcitabilității neuronale în migrenă), a peptidului înrudit cu gena calcitoninei (CGRP) - eliberat de fibrele trigeminale ce însoțesc vasele meningeale și care crește sensibilitatea nociceptorilor meningeali - și a factorului de creștere a fibrelor nervoase (NGF), un inductor de hiperalgezie prin diverse mecanisme, inclusiv degranulare mastocitară. Concentrațiile de betaendorfină în același produs erau însă scăzute. Aceleași modificări se regăsesc și la nivelul probelor de sânge, cu excepția rezultatelor pentru parametrul NGF [17].

Mai aproape de cercetarea pe baza unor markeri obișnuiți, deja uzitați frecvent în practica clinică și în ton cu ipoteza neuroinflamatorie ce a devenit relativ recent din ce în ce mai investigată atât în privința etiologia migrenei, cât și a epilepsiei, există studii care arată că, în timpul unui atac migrenos, raportul neutrofile/limfocite ca marker inflamator în rândul pacienților cu migrenă este crescut comparativ cu grupurile control [18]. De asemenea, există studii ce au constatat o creștere a numărului de monocite în probele de sânge ale pacienților cu migrenă recoltate à jeun, corelat pozitiv cu creșteri ale proteinei $C$ reactive. Se cunoaște deja faptul că monocitele periferice pot pătrunde la nivel cerebral transformându-se ulterior în microglii cu rol în apariția durerii subsecvent eliberării de mediatori neuroinflamatori [19]. Se mai cunoaște, de asemenea, că, la două ore după debutul unui atac migrenos, crește activitatea factorului nuclear lanțul ușor kappa inductor al celulelor $\mathrm{B}$ activate ( $\mathrm{Nf}-\mathrm{kB}$ ) la nivelul monocitelor, urmată de activarea sintetazei de oxid nitric inductibile (iNOS) observată la 4 și 6 ore, cu descreștere la încetarea atacului [20].

\section{CONCLUZII}

Se descrie o variabilitate mare a etiologiei și a manifestărilor clinice ale cefaleei în populația pediatrică, punctându-se în același timp existența unei patologii 
de graniță, alertând astfel medicul de familie asupra necesității de a gândi diagnosticul cefaleei în pas cu ultimele evoluții în domeniu. În acest context, se reamintește faptul că, în rândul populației pediatrice, migrena este cea mai frecventă cefalee primară, urmată de cefaleea de tensiune. În privința cefaleei secun- dare, se prezintă un instrument mnemotehnic util (SNOOP4Y) pentru evaluare, în timp ce pentru zona de graniță se reține faptul că cefaleea epileptică, așa cum a fost aceasta definită de IHS în 2018, este o entitate rară ce necesită însă vigilență diagnostică.

Conflict of interest: none declared Financial support: none declared

\section{BIBLIOGRAFIE}

1. Matei D. Semne și simptome în pediatrie. In Matei D. (coordonator) - Esențialul în medicina de familie, 3th Edition, Editura Medicală Amaltea București, 2016, pp. 97-110.

2. lancu MA. Cefaleea. In Matei D. (coordonator) - Esențialul în medicina de familie, 3th Edition, Editura Medicală Amaltea București, 2016, pp. 197-199.

3. Matei D, Eremia IA. Cefaleea. In Matei D. (coordonator) - De la simptom la diagnostic în practica medicului de familie, Editura Medicală Amaltea București, 2018, pp. 43-46.

4. Headache Classification Committee of the International Headache Society (IHS) The International Classification of Headache Disorders, 3rd edition. Cephalalgia. 2018;38(1):1.

5. Kabbouche MA et al. Headache in Children and Adolescents. In Swaiman et al, eds. Swaiman's Pediatric Neurology. Principles and Practice, 6th ed., 2018, Elsevier, pp. 647-655.

6. Gofshteyn JS, Stephenson DJ. Diagnosis and Management of Childhood Headache.
Current Problems in Pediatric and Adolescent Healthcare 2016;46(2):36-51.

7. Orr SL et al. Paediatric migraine: Evidencebased management and future directions. Nat Rev Neurol. 2018;14(9):515-527.

8. Teleanu RI et al. Treatment of pediatric migraine: A review. Maedica - a Journal of Clinical Medicine. 2016;11(2):136-143.

9. Evans RW. Migraine Mimics. Headache. 2015;55(2):313-322.

10. Papetti $L$ et al. Headache as an Emergency in Children and Adolescents. The Journal of Headache and Pain 2015;16(Suppl 1):A142.

11. Saitowitz Z, Flamini R, Berenson F. Ictal Epileptic Headache: A Review of Current Literature and Differentiation From Migralepsy and Other Epilepsies. Headache. 2014;54(9):1534-1540.

12. Fanella $M$ et al. Ictal epileptic headache revealing non-convulsive status epilepticus in a case of eyelid myoclonia with absences. The Journal of Headache and Pain. 2015;16:105.

13. Sowell MK, Youssef PE. The Comorbidity of Migraine and Epilepsy in Children and Adolescents. Seminars in Pediatric Neurology 2016;23(1):83-91.
14. Kim DW, Lee SK. Headache and Epilepsy. Journal of Epilepsy Research. 2017;7:7-15.

15. Gameleira FT, Ataide L Jr, Raposo MCF. Relations between epileptic seizures and headaches. Seizure. 2013;22(8):622-626.

16. Cianchetti $C$ et al. Epileptic headache: $A$ rare form of painful seizure. Seizure. 2017; 52:169-175.

17. Van Dongen RM et al. Migraine biomarkers in cerebrospinal fluid: A systematic review and meta-analysis. Cephalalgia. 2017; 37(1):49-63.

18. Karabulut $\mathrm{KU}$ et al. The change of neutrophils/lymphocytes ratio in migraine attacks: A case-controlled study. Annals of Medicine and Surgery. 2016;10:52-56.

19. Peng YF et al. A relationship between absolute monocyte count and C-reactive protein in patients with migraine undergoing no pharmacological therapy. Clin Chem Lab Med. 2016;54(9):249-251.

20. Michalak $S$ et al. Increased Serum CD14 Level Is Associated with Depletion of TNF- $\alpha$ in Monocytes in Migraine Patients during Interictal Period. Int $\mathrm{J} \mathrm{Mol} \mathrm{Sci.}$ 2017;18(2):398. 